\title{
RESOURCES, CAPABILITIES AND COMPETENCES FOR ECO-INNOVATION
}

\author{
Pablo DEL RÍO ${ }^{\mathrm{a}}$, Javier CARRILLO-HERMOSILLA ${ }^{\mathrm{b}}$, \\ Totti KÖNNÖLÄ ${ }^{c}$, Mercedes BLEDA ${ }^{\mathrm{d}}$ \\ ${ }^{a}$ Institute for Public Policies and Goods (IPP), Consejo Superior de Investigaciones, \\ Científicas C/Albasanz 26-28, 28037 Madrid, Spain \\ ${ }^{b}$ Institute for Economic and Social Analysis, University of Alcalá and Center for European Studies, \\ IE University, Plaza de la Victoria 2, 28802 Madrid, Spain \\ 'Insight Foresight institute (IFI), Avda de Concha Espina 8-1 Dcha, 28036 Madrid, Spain \\ ${ }^{d}$ Manchester Business School (MBS), The University of Manchester, \\ M13 9PL Manchester, United Kingdom
}

Received 17 December 2012; accepted 10 November 2013

\begin{abstract}
The existing literature on the determinants for the development and adoption of ecoinnovations has generally focused on analysing the influence of business strategies and external drivers (public policy and stakeholder impacts) on innovation processes in firms. Internal factors to the firm such as resources, capabilities and competences (RCCs), which are important drivers of business strategies and innovation performance, are seldom considered in the literature. This paper builds an integrated framework that incorporates the impact of those firm's internal factors and their interactions with external drivers on the development and adoption of eco-innovations. The relevance of those factors regarding several dimensions of eco-innovation is illustrated with case studies. It is shown that, while all RCCs are relevant for the development and uptake of ecoinnovations, their relevance differs across eco-innovation dimensions.
\end{abstract}

Keywords: eco-innovation, resources, capabilities, environmental strategy, case studies.

JEL Classification: B52, O30, Q55.

\section{Introduction}

There is voluminous literature on the determinants for eco-innovation defined as innovations that reduce the environmental impact of consumption and production activities (see Horbach et al. 2012; Belin et al. 2011; del Río 2009) for recent overviews of this literature). Most studies include three types of variables: regulation and policy determinants, supplyside determinants (technological capabilities, cost savings, appropriability conditions) and

Corresponding author Pablo del Río

E-mail:pablo.delrio@csic.es 
demand-side determinants (consumer preferences for environmentally-friendly products) (Horbach 2008). Firm internal variables, including the resources and capacities of firms, represent a crucial set of factors affecting eco-innovation.

However, the literature has generally focused on the analysis of the influence of business strategies and external drivers (public policy and stakeholder impacts) on eco-innovation in firms. Internal factors to the firm such as resources, capabilities and competences (RCCs), which are important drivers of business strategies and innovation performance, have seldom been considered in the empirical literature on eco-innovation, mostly because of the difficulty to include these factors into econometric models due to poor data availability. RCCs are usually limited to the inclusion of only one variable in econometric models, normally in the form of implementation of an environmental management system (Demirel, Kesidou 2011; Kesidou, Demirel 2012; Horbach 2008; Horbach et al. 2012; Wagner 2008; Rave et al. 2011). Other variables have also been used: ownership of an approved ISO 14001 or EMAS certification (Demirel, Kesidou 2011; Mazzanti, Zoboli 2006), relevant changes in organisational structures (Horbach 2008; Horbach et al. 2012), technological capabilities proxied by R\&D (Kammerer 2009; Horbach 2008; Horbach et al. 2012; Belin et al. 2011; Mazzanti, Zoboli 2006) and employee qualification (Horbach et al. 2012). While useful, those analyses may not grasp the multifaceted influence of those RCCs and their complex role in the ecoinnovation process.

In Carrillo-Hermosilla et al. (2010), we elaborated different eco-innovation dimensions and applied them in several case studies illustrating how the different eco-innovations scored on the different dimensions. In this paper, those eco-innovation dimensions are built upon (see Section 1). The role of internal resources of a firm in eco-innovating (and, more specifically, how RCCs act as crucial drivers for eco-innovation) is explored further.

Therefore, the aim of this paper is twofold:

1) To build an integrated conceptual framework to analyse the impact of external and internal drivers on the development and adoption of eco-innovations. This framework integrates several streams of the literature and incorporates the impact of firm's internal factors (RCCs) and their interactions with external drivers on the development and the adoption of eco-innovations. The framework builds on the key dimensions of eco-innovation we have previously developed (Carrillo-Hermosilla et al. 2010).

2) To illustrate the relevance of the RCCs regarding several dimensions of eco-innovation with case studies. It is shown that, while all RCCs are relevant for eco-innovations, their relevance differs across the eco-innovation dimensions.

Accordingly, the paper is organised as follows. The next section briefly describes the dimensions of eco-innovation. Section 2 develops an integrated analytical framework for the analysis of key internal factors to eco-innovation, focusing on RCCs. In Section 3, the RCCs relevant for different dimensions are highlighted for different eco-innovation cases. Section 4 discusses the relationship between the RCCs and the eco-innovation dimensions. The last section presents conclusions. 


\section{The dimensions of eco-innovation}

The eco-innovation dimensions, developed and discussed in detail in Carrillo-Hermosilla et al. (2010), can be summarised as follows.

\subsection{Design dimensions of eco-innovation}

There are two different design rationales to innovations, redesign/minimization, with the incremental/radical nature of technological change and the degree of impacts on the system. As a result, three different approaches to identify the role and impacts of eco-innovations are proposed (Carrillo-Hermosilla et al. 2010):

- Component addition: development of additional components to minimize and repair negative impacts without necessarily changing the process and system that generate those impacts, as with "end-of-pipe" technologies.

- Sub-system change refers to eco-efficient solutions and the optimisation of sub-systems, leading to the improvement of the sub-system and a reduction of its negative environmental impacts.

- System change involves the redesign of systems towards eco-effective solutions, reducing the environmental impacts on the ecosystem and society at large. Moving towards system change challenges companies and society to redefine their production and behavioural patterns.

\subsection{User dimensions of eco-innovation}

Two user dimensions of eco-innovation are considered (Carrillo-Hermosilla et al. 2010):

- User development: To systematically involve users in the innovation process, firms need a special competence to identify which users are capable of providing valuable inputs in innovation projects (Rondinelli, London 2003).

- User acceptance: A clear understanding of users' needs and wants is crucial for successful new products. Establishing specific target markets for greener products and assessing market needs are important for market success.

\subsection{Product service dimension in eco-innovation}

To be radical, product service innovation requires a redefinition of the product service concept and the way it is provided to customers. A "product service system" for developing sustainable business models (Markides 2006; Mont 2002; Williams 2007) focuses on the delivery of a "function" to the customer that might, in practice, mean the provision of combinations of products and services that are capable of "jointly fulfilling user needs" (Goedkoop et al. 1999).

Furthermore, this dimension of eco-innovation stresses the relevance of a supply chain perspective in eco-innovation. It calls for a supply chain shift during the production, consumption, customer service, and the post-disposal of products (Linton et al. 2007). 
Therefore, the following sub-dimensions were deemed crucial (Carrillo-Hermosilla et al. 2010):

- Change in product service deliverable consists of changes in the product/service delivered and changes in the perception of the customer relation.

- Change in product service process consists of changes in the value-chain process and relations that enable the delivery of the product service.

\subsection{Governance dimension of eco-innovation}

Overcoming barriers to radical eco-innovations requires major governance innovation in both the private and public sectors. From the public sector point of view, those solutions can deal with one of the functions of environmental governance, including exclusion of unauthorized users, regulation of authorized resource use and the distribution of the respective benefits (market-based instruments), provision and recovery of costs, monitoring, enforcement, conflict resolution and collective choice (Paavola 2007). From a company perspective, governance invites managers to explore the wider role of business in society, i.e., to renew their relationships with other stakeholders, particularly with the government. Governance pinpoints the importance of public-private collaboration in eco-innovation.

Eco-innovations involve a combination of elements pertaining to all those dimensions, which play a significant role in understanding the multi-faceted nature of eco-innovations and their diversity. When they are addressed together, they form a comprehensive framework for the analysis of eco-innovation.

\section{Analytical framework}

In Section 2.1, we outline the main theoretical approaches currently used in analyses of RCCs of firms as internal factors influencing innovations in general. Furthermore, in Section 2.2 we elaborate on links between those internal factors with firm external factors, which we deem relevant for eco-innovation. The combination of approaches including the Resource-Based-View of the firm (RBV), the dynamic capabilities, the evolutionary economics and the corporate environmental strategy literature provides a suitable theoretical basis for our analysis because they emphasise the importance of resources, capabilities and motivations/pro-activeness in each of the aforementioned eco-innovation dimensions.

\subsection{Relevant theoretical approaches for the analysis of RCCs and eco-innovation}

What follows is a brief overview of the main ideas of existing approaches dealing with RCCs, useful for explaining eco-innovation processes in companies.

The $R B V$ argues that the competitive advantage and innovation activities of firms strongly depend on their valuable, inimitable and non-substitutable resources or capabilities, located within the organisation (Russo, Fouts 1997). Three main concepts are used by this approach (Cohendet et al. 1999; Katkalo et al. 2010):

- Resources are firm-specific assets whose value is context dependent. Tangible resources include financial reserves and physical resources, whereas intangible resources en- 
compass reputation, organisational culture, technology, customer relationships and human resources.

- Competences (or capabilities) are resources, which result from activities that are performed repetitively in a firm. Organisational competences enable economic tasks to be performed that require a collective effort, and they are usually underpinned by organisational processes or routines (Nelson, Winter 1982; Dosi et al. 2000).

- Dynamic capabilities are the capacities of an organisation to purposefully create, extend and modify its resource base (Helfat et al. 2007: 4) to both address and shape rapidly changing business environments (Teece et al. 1997).

According to the RBV, firms are heterogeneous with respect to their endowments of resources/capabilities, which are difficult to transfer between organisations (Levin et al. 1987). Resources/capabilities are accumulated overtime by firms (Worch, Markard 2010) and are sticky, at least in the short-term (Teece et al. 1997; Hart 1995). Some of these RCCs may be particularly relevant for eco-innovation, as shown in the following sections.

The dynamic capabilities (DCs) approach is rooted in the RBV (Helfat, Peteraf 2009; Ambrosini et al. 2009). It extends the RBV and emphasizes the key role of strategic management in appropriating, adapting, integrating and reconfiguring the internal and external organisational skills, resources and functional competences of the firm to match the requirements of a changing environment (Teece et al. 1997). DCs alter a firm's resource base (Eisenhardt, Marin 2000). The link between organisational skills and eco-innovation is also suggested by some empirical studies. For example, Bloom et al. (2010) show that better-managed firms (i.e., managerial quality) are also significantly less energy-intensive because modern management involves production systems that minimise energy use, and good management practices enable firms to generate and implement energy saving ideas. Organisational environmental capabilities and new organisational tools positively affect eco-innovation in several empirical studies (Antonioli et al. 2013; Kesidou, Demirel 2012; Horbach 2008; Horbach et al. 2012).

In this paper, RCCs are those controlled by the firm, which fundamentally enable it to eco-innovate. Some are created/accumulated, while others are acquired from other organisations, through collaboration with other firms or networking. While some resources are outside the firm, they can be captured by the firm through involvement in networks (networking) (Worch, Markard 2010). Eco-innovations, especially of the systemic type, necessarily involve cooperation between multiple stakeholders, including research centres, universities, consumers, competitors, suppliers and governments.

The idea that knowledge constitutes a source of distinctiveness and a crucial resource for the successful performance of firms directly relates the evolutionary theory to the capabilities-based approach of the firm (Foss 1993; Teece, Pisano 1994; Langlois, Robertson 1995; Foss, Knudsen 1996). According to Schreyögg, Kliesch-Eberl (2007), the identification of social and behavioural features of resources and capabilities has been informed by insights from evolutionary economics. Barney (2001) stresses the "obvious analogies" existing between the RBV and evolutionary economics: routines (from evolutionary economics) are an example of firm resources and capabilities, while firm heterogeneity is an important part of both theories.

In the evolutionary perspective, the capabilities of the firm represent idiosyncratic knowledge and are embedded in its organisational routines (Nelson, Winter 1982; Dosi et al. 2000), 
shaping and yielding organisational action and behaviour (Metcalfe, Ramlogan 2005). The innovation process is highly path-dependent and cumulative (Dosi 1988). Every firm tends to follow its specific technological trajectory depending on its technological capabilities and knowledge base. Firms build their base of knowledge and so exhibit significant differences in terms of technological capacities (Belin et al. 2011). The creation of knowledge is a consequence of a path-dependent process and, thus, it is partly tacit and firm-specific (Nelson 1991; Hodgson 1998). Organisational routines involve problem-solving capabilities and decision rules governing the relationship between the firm and its environment and intra-firm relationships. Learning involves the building of new representations of the environment, which is largely unknown and changing and the development of new capabilities that enable to exploit the opportunities and face the challenges this environment offers.

Both approaches (i.e., RBV and evolutionary economics) highlight that many factors affect the innovative process, not only factors external to the firm but also its internal resources (Belin et al. 2011). According to the evolutionary perspective, innovation arises through a systemic process, with interconnectedness and dynamic interactions between the different actors and internal and external factors influencing the innovation process. Firms constantly interact with their changing environment and continuously face new challenges that require the modification of existing knowledge or the generation of radically new one (Nelson 1991; Hodgson 1998). The interactions that firms maintain with their environment are considered a source of selective pressure but also ways of accessing external sources of knowledge. This is a crucial perspective to analyse eco-innovation processes, which have been shown to depend on a combination of internal and external factors to the firm (del Río 2009), and where cooperation and external knowledge sources have been shown to be a crucial driver, even more important than for "normal innovation" (Belin et al. 2011; Horbach 2008).

Finally, another relevant approach is the corporate environmental strategy literature. A firm's environmental strategy refers to a firm's strategy to manage the interface between its business and the natural environment (Aragón-Correa, Sharma 2003). One research stream focuses on the drivers to the implementation of environmental strategies by firms (either reactive or proactive) and the (mostly external) factors that led to this adoption. Two main influences are stressed: firms are motivated by either environmental regulation or by their stakeholders (e.g., Henriques, Sadorsky 1999). The pre-eminence of external factors has been softened in more recent contributions; however, while internal factors to the firm have gained relevance, such as internal resources. These include employee motivation, managerial attitude and motivations (Aragón-Correa, Rubio-López 2007; González-Benito, J., GonzálezBenito, O. 2006; Sharma, P., Sharma, S. 2011).

Therefore, some variables influencing the implementation of environmentally-proactive strategies depict internal company features, although stakeholder pressure is distinguished as a central determinant factor in this literature.

Strategy (stressed by this literature) and RCCs (stressed by the RBV and DCs approaches) are concerned with the deployment and configuration of resources, processes and organisational structures in order to reach a specific goal (Worch, Markard 2010). Thus, strategy connects RCCs to eco-innovation. 


\subsection{Relating firm internal and external factors}

The aim of this subsection is to identify the interrelationships between the different factors acknowledged as important by the literature in order to provide a sound basis for the empirical analysis of drivers of eco-innovation processes at the firm level.

The first challenge is to relate the internal factors between each other. Company capabilities and competences depend on company characteristics, the existence of resources within the company and the ability to assemble, integrate and manage those resources. In turn, competences and capabilities directly affect corporate strategy and firm performance. Environmental strategies depend on internal resources and capabilities, including the environmental commitment of top managers.

On the other hand, the RBV and DCs approaches invite consideration of managerial strategies for developing new capabilities (Teece et al. 1997; Teece, Pisano 1994). Thus, corporate strategies (and firm performance) dynamically affect the availability of internal resources.

These internal factors interact between each other, but also with the external factors, which include demand, public policy and competitors (Russo, Fouts 1997) that affect and are affected by internal factors. This interaction shapes the environmental strategy of the firm, leading to the development or adoption of eco-innovations. The adoption of an ecoinnovation leads to changes at the firm level. These changes are mostly related to human resources and physical infrastructure but, if sufficiently pervasive, such adoption may also significantly affect the organisation and the structure of the firm.

In turn, eco-innovation opens up the possibility for new policies since they facilitate the tackling of an environmental problem or reduce the costs of so doing. Furthermore, eco-innovators have an incentive to lobby and influence new legislation favourable to their interests. In turn, as suggested by the Porter hypothesis (Porter, van der Linde 1995), policy interventions shape the organisational structure of the firm and affect the development of RCCs relevant for eco-innovation. Figure 1 summarises these relationships.

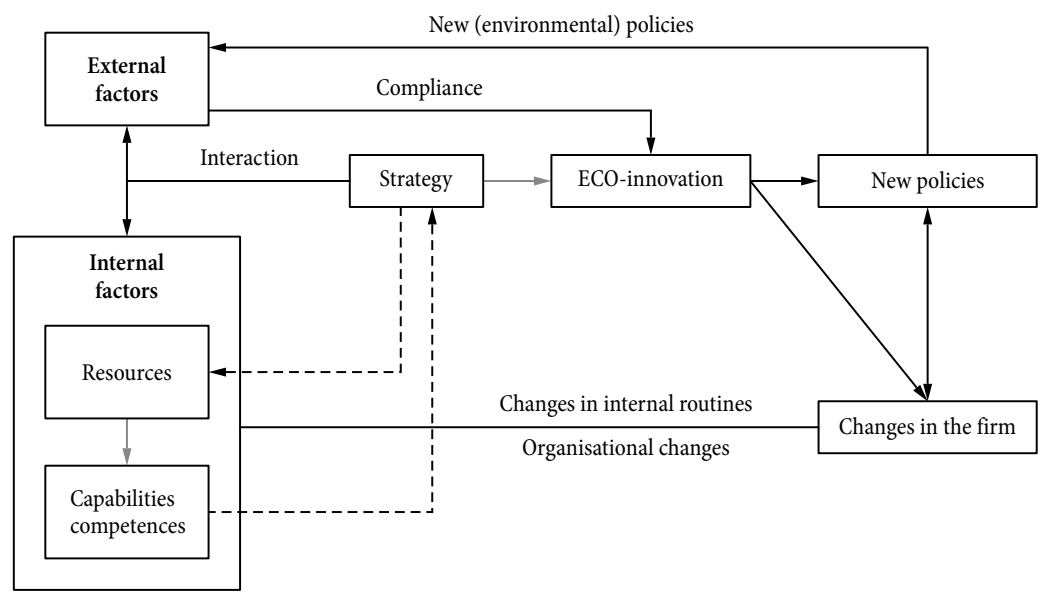

Fig. 1. The interactions between RCCs and other determinants of eco-innovation Source: Own elaboration. 


\section{The empirical study}

The study of eco-innovation can benefit significantly from empirical analyses, which grasp the details of specific eco-innovation types and their dimensions (Carrillo-Hermosilla et al. 2010, 2009). Learning through case-studies can provide deeper insights into how and why eco-innovation has succeeded and how RCCs facilitate or hinder this process (OECD 2012). Such a bottom-up approach offers insights, which would help to discover the peculiarities of relevant RCCs in the eco-innovation process.

A case study approach is ideal for generating theoretical and pragmatic insights from empirical observations when little is known about a phenomenon and when there is disagreement within the literature (Eisenhardt, Graebner 2007). As noted by Helfat, Peteraf (2009), the analysis of dynamic capabilities is still in its infancy as a field of inquiry and case studies can be especially useful in early stages of research in an area. This is also the case in the analysis of RCCs for eco-innovation. Case studies are a relevant source of empirical evidence on the details of eco-innovations and firm internal drivers. Therefore, we conducted multiple case studies to illustrate the relevance of different RCCs for several eco-innovation dimensions.

Our unit of analysis was the eco-innovation phenomenon. Information sources included internal company reports, company profiles, product catalogues and field notes. We analysed eco-innovations from different countries and sectors, in order to observe the phenomenon of eco-innovation in all its complexity and diversity, as advocated by exploratory case study research (Eisenhardt, Graebner 2007; Ellinger et al. 2005; Wagner, Llerena 2011). Furthermore, those eco-innovations show different maturity levels and degrees of disruption, faced several barriers to their development/adoption and were affected by different policies (Table 1). The choice of different sectors was justified given the large sectoral variation found regarding ecoinnovation drivers (Mazzanti, Zoboli 2006; Wagner, Llerena 2011). The cases were chosen to describe the diversity of eco-innovations rather than as examples of best practice. Their main common nominator lies in the ability of their proponents to address different dimensions in a combined manner. Table 1 summarises these case studies. This section discusses the results from the case studies exploring the relevance of RCCs for each eco-innovation dimension.

\section{Case 1. Ecocement (construction, Japan)}

Design dimensions. The pilot plant test was conducted by a consortium initiated by Taiheiyo with three other companies. The early exploratory phases of designing Ecocement were undertaken by a Committee supported by academics and several Ministries and sought to identify sustainable manufacturing technology options. Consequently, one key capability to integrate the design dimensions of eco-innovation in company practice was the engagement of multidisciplinary teams and external partnerships with other companies and research institutes.

User dimensions. This project widened the spectrum of customers of Taiheiyo beyond offering cement to the construction business to provide a solution to new clients (municipalities) with waste disposal problems and potential new customers interested in other raw materials separated from the waste but unsuitable for cement production. The company's capability to understand customers' needs, preferences and uses of products is relevant for the discovery of new business opportunities. 
Table 1. Summary of the case studies

\begin{tabular}{ll}
\hline \multicolumn{1}{c}{ Case studies } & \multicolumn{1}{c}{ Description/main features with respect to dimensions } \\
\hline $\begin{array}{l}\text { Ecocement } \\
\text { (construction, }\end{array}$ & $\begin{array}{l}\text { Ecocement was developed in 1999 by Taiheiyo Cement Corporation, a leading } \\
\text { Japan) }\end{array}$ \\
& $\begin{array}{l}\text { Ministry of International Trade and Industry (MITI). Ecocement is a hydraulic } \\
\text { cement produced from municipal waste incineration ashes. It provides a double }\end{array}$ \\
& $\begin{array}{l}\text { environmental benefit: a reduction in the extraction of resources and wastes. } \\
\text { Ecocement received several awards in 2005. External drivers were increasingly } \\
\text { strong legislative and stakeholder pressure on the sustainability of the Japanese } \\
\text { cement industry. It is characterized by sub-system change, user development, } \\
\text { product-service process and governance innovation. }\end{array}$ \\
\hline
\end{tabular}

EcoWorx, EcoWorx was introduced in 1999 by Shaw Commercial as a replacement for carpet backing traditional carpet tile backing made from PVC. In comparison with standard carpet (industrial backing, it constitutes a re-design as it is 100 per cent PVC-free and recyclable. It processes, USA) involves radical changes in the design and product-service dimensions, leading to a more environmentally friendly product system with closed-loop solutions. It involved the re-design of the product value chain and the building up of the reverse logistics system.

The Green Hotel Developed by NH in partnership with Siemens, this eco-innovation arose in 2008 Project (services, to enhance the rational use of energy. It is a design of component addition and Spain) customizes the key cards for guests' entry into the hotel rooms. Guests mark their preferences on lighting and temperature when they check-in and the room is lit and heated to their tastes. It saves energy and it is a step in the customized service provided to clients.

The automated This system transports waste at high speeds through an underground pipe vacuum system network to a centrally located waste transfer station where it is compacted, for waste sealed in containers and then carted away. Resources can be collected from collection several drop-off points in single buildings, restaurants and shopping complexes. (resources It was developed by Envac, with its first pilot project in the 1960s. Thanks to management, on-going R\&D, Envac has received several patents, achieving a leading position Sweden) in the market. It is a multidimensional innovation in which different factors interact in a favourable way. It radically changes the way the waste is sorted and collected.

Hybrid Synergy Toyota patented the HSD and introduced the Prius in 1997 in Japan. It combines Drive (Transport, a petrol engine and an electric motor. Under urban traffic conditions, only the Japan) electric motor drives the vehicle. When the vehicle is on the motorway, the petrol engine powers the vehicle and charges the battery. Therefore, environmental improvements stem from regenerative braking and from shutting off the internal combustion engine when the car is stopped. This eco-innovation is characterized by component, sub-system and governance changes.

Note: see Carrillo-Hermosilla et al. (2009) for further details.

Product service dimensions. In 2001, Taiheiyo collected 6.2 million tonnes of waste materials from 190 companies in 22 industries, and recycled them to produce Ecocement. It developed an information network on waste materials on the Internet, connecting it with other companies. Accordingly, the product service dimensions call for particular consideration of the overall business strategy and logic, including the convergence of supply chains.

Corporate governance dimensions. Ecocement was developed through the cooperation of public and private Japanese institutions. Taiheiyo had an extended view of its production system, to include suppliers, customers, government and civil society as partners in the innovation process. 


\section{Case 2. EcoWorx, carpet backing (industrial processes, USA)}

Design dimensions. Change began within the company's R\&D department. Early environmental changes in the company (waste reduction and resource conservation) were followed by changes in the materials for carpets. Shaw developed existing initiatives further and introduced EcoWorx in 1999. Consequently, key design capabilities were the stock of existing initiatives and in-house engineering abilities.

User dimensions. The successful diffusion of EcoWorks was largely based on the fact that customers considered that it performed well both in terms of its environmental impacts and its functionality and quality. Customers had little impact on the development of this ecoinnovation but consumer acceptance obviously had a great impact on its diffusion.

Product service dimensions. Through its environmental guarantee, Shaw committed to collecting all EcoWorx products to recycle them into more EcoWorx at no charge. As a result, it set up a new reverse logistics system to manage the return flows of carpets. It developed a nationwide collection network, which involved collaborating with businesses across the US in establishing recycling centres for post-consumer carpet. Accordingly, Shaw organised interactions between different actors in the value chains and networks, emphasizing its broader view of innovation beyond internal management systems and the factory gates as a key capability in this dimension.

Corporate governance dimensions. Shaw's clear vision and alignment of its strategy with the characteristics of the industry was an excellent guidance in this process of change and environmental commitment. Another relevant capability was its corporate culture, favourable to change in general and particularly proactive with regard to environmental protection and innovation.

\section{Case 3. The Green Hotel Project (services, Spain)}

Design dimensions. This eco-innovation is a component addition (the computer control system) but not a major system change. It requires little changes in the way the hotel business is run, although significant environmental, technical and marketing information to identify needs and ground ideas was required from $\mathrm{NH}$.

User dimensions. This eco-innovation neither was developed by $\mathrm{NH}$, nor was it an "onthe-shelf" technology. The technology supplier (Siemens) and user (NH) had to collaborate closely to implement this technology. This proactive role to engage in close collaboration with other stakeholders was a relevant capability.

Product service dimensions. This eco-innovation does not involve major changes in the product service delivered and in the perception of the customer relation. A major advantage for the firm is customization and customer loyalty, but there is no major change regarding the value chain, the organisation and provision of the hotel service.

Corporate governance dimensions. The internal strategy and proactive stance on the environment of $\mathrm{NH}$, aimed at reducing energy costs, building a sustainability image and encouraging the guests' loyalty, facilitated its implementation.

\section{Case 4. Automated vacuum system for waste collection (waste management, Sweden)}

Design dimensions. The combination of company dust vacuuming expertise (accumulated $R \& D)$, entrepreneurial initiative to explore and test radically new approaches in exploiting exist- 
ing vacuum technology know-how to new areas and a possible new client, Sollefteå Hospital, led to the invention and several patents. The idea was to apply principles of dust vacuum systems to waste collection, offering a radically different way of sorting and collecting municipal and industrial waste.

User dimensions. The company managers initially worked together with a hospital to pilot the system. The breakthrough was achieved when the first vacuum system was installed in the completely new residential district of Ör-Hallonbergen, providing crucial experience for business development. Later on, end users (often households) were informed on how to change their way of dealing with waste and to correctly apply the system. Envac has worked actively identifying new customer segments and working together with potential users to overcome the obstacles.

Product-service dimensions. The installation and management of vacuum waste collection systems require a radically different way of organising the sorting and waste collection service compared to container and vehicle-based waste collection. Furthermore, the vacuum system builds on radically different technologies, expertise and partners throughout the value chain. Moreover, the capital investments required to install the system infrastructure are considerable. Hence, a sound financial situation and expertise in providing financial consulting played a crucial role. Envac developed marketing approaches to capture new clients in existing and new customer segments.

Corporate governance dimensions. The municipal governments in Sweden played an important role in the development of this eco-innovation. Collaboration with the municipalities provided an opportunity to apply the system and identify its strengths and weaknesses for additional improvements. Furthermore, governments often play an important role as the articulator of the demand for the eco-innovation and in the financing of the required investments. The governance of the change from conventional waste collection to vacuum systems requires proactive change management by the waste collection service provider.

\section{Case 5. Hybrid Synergy Drive (Transport, Japan)}

Design dimensions. This eco-innovation was developed by Toyota through a very ambitious R\&D plan, followed by a strong marketing campaign, showing the relevance of the company's in-house engineering abilities.

User dimensions. Although users played a very limited role in its initial development, later technological improvements were the result of R\&D investments adapting the features of the car as the company learned from consumer feedback. Regarding user acceptance, persuading the buying public that hybrids are a mainstream option continues to be a challenge. Again, this called for a clear understanding of users' needs, to overcome the lack of knowledge and minimize any distrust on the functionality properties of the Prius.

Product-service dimensions. If, to be radical, product service innovation requires a redefinition of the product-service concept and how it is provided to the customer, then the Prius is not a radical change. As to the product-service process (supply chain), the focus of management and operations remains on local optimisation of the energy efficiency of the car during driving, but does not shift to the entire supply chain (that is, production, consumption, customer service and post-disposal of products). 
Corporate governance dimensions. A major motivation for managers' commitment to develop the Prius was the "early mover advantage". The company wanted to be sure that if alternatives to the petrol-based internal combustion engine started to gain traction, they would be driving the change, not being driven by it. In this long-term bet, short-term benefits were not expected. In 1993, following the lead of Toyota's Chairman, a committee to research cars for the 21st century was created, leading to the Prius. Significant levels of R\&D investments were required. Therefore, high degrees of top management commitment were necessary to get the project off the ground, especially in the initial stages, when the prospects of technological and market success were unclear.

\section{Discussion: relating resources, capabilities and eco-innovation dimensions}

The theoretical discussion and the case studies suggest that the development and uptake of eco-innovation are clearly affected by RCCs. These RCCs modulate the linear pressure (policies)-response (eco-innovation) model typical of mainstream environmental economics, that treats firms and technologies as a black box. Our findings indicate that RCCs affect how a given external stimulus finally translates into the development or adoption of an eco-innovation and that innovating in different dimensions depends on the availability of RCCs. The relative importance of the RCCs differs across the different dimensions.

Design dimension. The case studies pinpoint the importance of RCCs for the development and uptake of eco-innovations especially of (sub-)systemic changes. The stock of existing initiatives and tools for designing eco-innovations were crucial in the Prius and EcoWorx cases. Human resources often make the difference. The greater the level of change, the greater the required skills of employees. Concerned and aware employees often act as technology champions (Wagner, Llerena 2011). (Sub-)systemic changes usually involve changes in the supply chain, lead firms to collaborate with other stakeholders in the supply chain and emphasize the important role of networking and the capacity for stakeholder integration, as shown by the Ecocement, EcoWorx and Envac cases. This capacity for stakeholder integration has also been shown to play an important role in eco-innovation by Wagner, Llerena (2011).

Systemic changes also require large capital outlays, as shown by Envac, which suggests that a sound financial situation by the firm is critical in this context. Physical resources play a major role because an existing, non-depreciated, highly capital-intensive installed base acts as a deterrent to systemic change. This was the case in the first stages of Envac. In addition, our findings suggest the importance of top-management support, as indicated in the Prius. The greater the level of change, the greater the level of top-managers' commitment required.

In contrast, the $\mathrm{NH}$ case shows that incremental eco-innovations require lower levels of RCCs, as argued by Ambrosini et al. (2009) for innovations in general. Neither large capital outlays, nor exceptional in-house knowledge, human resources or networking capabilities were required in this case.

User dimension. The more radical and systemic the change, the more important it is to engage with potential users in order to build new successful systems. Thus, the interaction with the user triggers market diffusion but also redefines the innovation. However, this interaction requires in-house knowledge and employee skills, which are crucial to identify which users 
can provide valuable inputs in the innovation process, i.e., to involve users in the innovation process (user development), to have a clearer understanding of user needs (user acceptance) and to allow users to correctly implement or use the technology, as suggested by Ecocement. Such dynamic capabilities can be obtained through a close relationship between the firm and its users. User engagement is however conditioned by the reputation of the company and the innovation itself. Here, marketing departments may play a crucial role in identifying and influencing users' needs and wants and capturing new clients, as illustrated by Envac. Also, personal contacts and the capacity to engage in networks may allow firms to anticipate the acceptance of the eco-innovation and to better know users' needs. The involvement of users (first customers) in the innovation process was crucial in Envac, whereas it was modest in EcoWorx and NH, although NH closely collaborated with its technology provider (Siemens).

Regarding user acceptability, both user-friendly eco-innovations have required an understanding of the users' needs, although they represent two different approaches. The NH case shows that an incremental eco-innovation not requiring drastic changes in users' behaviour increases the likelihood of being successfully implemented. In contrast, EcoWorx has led to changes in users' behaviour, but its good attributes in terms of functionality, quality and environmental impact have facilitated its diffusion.

Product service dimension. The development of a new product service concept requires new knowledge and expertise, which may not be compatible with the existing knowledge accumulated by the firm. Hence, the involvement in new and external stakeholder networks can be highly valuable in offering this new knowledge and expertise (Ecocement).

On the other hand, changes in the product service deliverable involve changes in the perception of the customer relation, i.e., the existing customer relationships are affected. The company should assess whether existing consumers perceive such change negatively, whether there might be new customers and what strategies the company should follow in order to attract them. Ideally, the new product service concept may lead to more cohesive value chains and a stronger customer loyalty. This relevance of a supply chain perspective in eco-innovation is illustrated by Ecocement.

Significant capital outlays and/or a brand new infrastructure might be required to implement the new product-service concept. Again, this suggests the importance of the availability of financial and physical resources, as shown by Envac and EcoWorx. Furthermore, employee motivation and attitude can play an important role (EcoWorx). Top-management commitment and a highly proactive attitude of the employees is required if the new concept involves a new vision of the company business model. In EcoWorx and Envac, radical changes in the product service concept were fostered by top-management commitment. In contrast, $\mathrm{NH}$ does not involve a redefinition of the product-service component.

Finally, since changes are required in the existing value networks, this involves the formation of new networks, collaboration and partnerships with new actors. Thus, the capacity to get involved in new networks and/or build new ones is particularly important, as illustrated by the formation of new public-private partnerships in Ecocement.

Governance dimension. Governance efforts re-position the eco-innovation in the company activities as a whole but also within the wider societal context, in particular with the public sector. New relationships with the public sector are facilitated by a good company reputa- 
tion. Building a "green" image improves this reputation. But reputation needs to be credible. Thus, top-managers commitment with environmental issues is particularly important, as exemplified by EcoWorx, Envac and Prius. This is more necessary the more radical the ecoinnovations are, since these lead to large short-term costs and mostly long-term pay-offs, as illustrated by Toyota developing the Prius over decades. In contrast, eco-innovations which result in cost-savings in the short-term without large capital outlays do not require such level of commitment $(\mathrm{NH})$, since they are part of the "normal" company business. Renewing the relationship with other stakeholders suggests the importance of building new networks and public-private collaboration (Ecocement).

The above discussion allows us to derive some preliminary hypotheses, to be tested in future research:

1. In-house RCCs positively affect the development and uptake of eco-innovations. RCCs matter and affect how a given external stimulus (i.e., public policies) finally translates into an eco-innovation. In particular, knowledge and skills, customer relationships, financial reserves, physical resources, reputation, motivations and attitude, human resources, personal contacts and networking are all expected to provide a positive influence on eco-innovation.

2. Different dimensions require (are activated by) the availability of different RCCs. While all RCCs are relevant for eco-innovation, the RCCs required are also different for different eco-innovations, since they activate different dimensions (Table 2).

3. RCCs for eco-innovation are interrelated. There are reinforcing effects, synergies and conflicts between different RCCs required for eco-innovation. For example, a proactive environmental strategy clearly depends on the capabilities of managers. The ability to engage in networks (partly) depends on the accumulation of knowledge.

Table 2. Relating dimensions and RCCs

\begin{tabular}{|c|c|c|c|c|c|c|c|c|c|}
\hline & 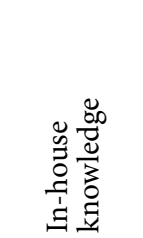 & 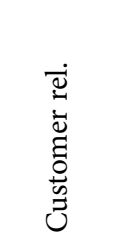 & 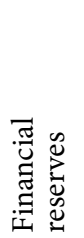 & 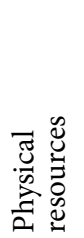 & 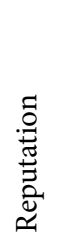 & 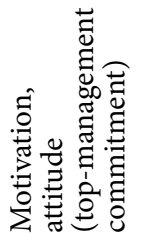 & 怘 & 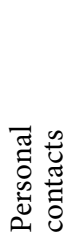 & 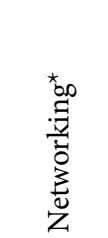 \\
\hline Design & (5) & & (4) & (4) & & (5) & $(2,5)$ & & $(1,2,4)$ \\
\hline User & $(1,2,3,5)$ & $(1,3,4)$ & & & (4) & & $(1,2,3,5)$ & (4) & $(4)$ \\
\hline $\begin{array}{l}\text { Product } \\
\text { service }\end{array}$ & (2) & (4) & (4) & (4) & & $(2,4)$ & (2) & & $(1,2)$ \\
\hline Governance & & & & & & $(2,3,5)$ & & & $(1,4)$ \\
\hline
\end{tabular}

Source: Own elaboration. ${ }^{*}$ Capability to get involved in networks. Note: numbers between parentheses refer to the case studies, which show the relevance of each RCC on the respective dimension: $1=$ Ecocement; 2 = EcoWorx; 3 = NH; 4 = Envac; 5 = Prius. 


\section{Conclusions}

This paper has illustrated how RCCs influence the development and uptake of eco-innovations and how different eco-innovation dimensions require different RCCs.

In general, the more radical the eco-innovation, the higher the level of RCCs required. Critical RCCs are in-house knowledge, employee skills, top-management commitment, a sound financial situation and networking capacity, which is partly coincidental with Wagner, Llerena (2011). Specific RCCs are more relevant for some dimensions than for others. For example, in-house knowledge and employee skills are crucial for the user dimension, whereas networking capacities are more critical for the product-service dimension.

Our results suggest that governments willing to promote eco-innovation should take those RCCs into account. Traditional environmental policies (command-and-control or market-based) are a driver in all our eco-innovation cases, since they affect the profitability of eco-innovation compared to other alternatives. However, they are unlikely to be sufficient to induce eco-innovation. Other instruments which influence eco-innovations indirectly by affecting relevant RCCs of firms should also be adopted. Therefore, policies should aim at activating or accumulating specific RCCs which prove particularly relevant for different ecoinnovation dimensions. In this context, supporting R\&D investments, top-management commitment, training of the workforce, user involvement and networking might be particularly useful, especially in small firms. These may lack the financial and human resources to develop these capabilities by themselves (Kammerer 2009). Which instruments are most suitable for this task represents a fruitful line of future research.

The analysed case studies were useful to derive some preliminary hypothesis from the theoretical framework and the discussion on eco-innovation dimensions. However, this approach has limitations regarding testing and the general is ability of the results thus obtained. Therefore, further analysis with quantitative techniques is a task to which the authors are committed in their future research. In particular, multivariate analysis techniques, including factorial and cluster analysis, would allow us to identify which RCCs are more relevant for which dimension, using firm-level data.

\section{References}

Ambrosini, V.; Bowman, C.; Collier, N. 2009. Dynamic capabilities: an exploration of how firms renew their resource base, British Journal of Management 20(Supplement s1): S9-S24.

http://dx.doi.org/10.1111/j.1467-8551.2008.00610.x

Antonioli, D.; Mancinelli, S.; Mazzanti, M. 2013. Is environmental innovation embedded within high performance organizational changes? The role of human resource management and complementarity in green business strategies, Research Policy 42(4): 975-988.

http://dx.doi.org/10.1016/j.respol.2012.12.005

Aragón-Correa, J.; Sharma, S. 2003. A contingent resource-based view of proactive corporate environmental strategy, Academy of Management Review 28: 71-88.

Aragón-Correa, J. A.; Rubio-López, E. 2007. Proactive corporate environmental strategies: myths and misunderstandings, Long Range Planning 40(3): 357-381.

http://dx.doi.org/10.1016/j.lrp.2007.02.008 
Barney, J. B. 2001. Resource-based theories of competitive advantage: a ten-year retrospective on the resource-based view, Journal of Management 27(6): 643-650. http://dx.doi.org/10.1177/014920630102700602

Belin, J.; Horbach, J.; Oltra, V. 2011. Determinants and specificities of eco-innovations. An econometric analysis for the French and German Industry based on the Community Innovation Survey, Cahier du GREThA 2011: 17.

Bloom, N.; Genakos, C.; Martin, R.; Sadun, R. 2010. Modern management: good for the environment or just hot air?, Economic Journal 120: 551-572. http://dx.doi.org/10.1111/j.1468-0297.2010.02351.x

Carrillo-Hermosilla, J.; del Río, P.; Könnölä, T. 2009. Eco-innovation. When sustainability and competitiveness shake hands. Palgrave Macmillan.

Carrillo-Hermosilla, J.; del Río, P.; Könnölä, T. 2010. Diversity of eco-innovations: reflections from selected case studies, Journal of Cleaner Production 18(10-11): 1073-1083. http://dx.doi.org/10.1016/j.jclepro.2010.02.014

Cohendet, P.; Llerena, P.; Marengo, L. 1999. Theory of the firm in an evolutionary perspective: a critical assessment, in Conference of the International Society for New Institutional Economics (ISNIE), 18-19 September 1999, Paris, France.

Demirel, P.; Kesidou, E. 2011. Stimulating different types of eco-innovation in the U.K.: government policies and firm motivations, Ecological Economics 70(8): 1546-1557. http://dx.doi.org/10.1016/j.ecolecon.2011.03.019

Dosi, G. 1988. Sources, procedures and microeconomic effects of innovation, Journal of Economic Literature 26(3): 1120-1171 [online], [cited 12 September 2012]. Available from Internet: http:// www.jstor.org/stable/2726526

Dosi, G.; Nelson, R. R.; Winter, S. G. (Eds.). 2000. The nature and dynamics of organizational capabilities. Oxford University Press.

Eisenhardt, K. M.; Graebner, M. E. 2007. Theory building from cases: opportunities and challenges, Academy of Management Journal 50(1): 25-32. http://dx.doi.org/10.5465/AMJ.2007.24160888

Eisenhardt, K. M.; Martin, J. A. 2000. Dynamic capabilities: what are they?, Strategic Management Journal 21(10-11): 1105-1121. http://dx.doi.org/10.1002/1097-0266(200010/11)21:10/11<1105::AID-SMJ133>3.0.CO;2-E

Ellinger, A. D.; Watkins, K. E.; Marsick, V. J. 2005. Case study research methods, in A. Swanson, E. F. Holton (Eds.). Research in organizations: foundation and methods of inquiry. San Francisco: Berret-Koehler Publishers, 327-350.

Foss, N. 1993. Theories of the firm: contractual and competence perspectives, Journal of Evolutionary Economics 3: 127-144.

Foss, F.; Knudsen, K. (Eds.). 1996. Towards a competence theory of the firm. Routledge.

Goedkoop, M. J.; van Halen, J. G.; teRiele, H.; Rommens, P. J. M. 1999. Product service systems: ecological and economic basics. Vrom EZ, The Hague.

González-Benito, J.; González-Benito, O. 2006. Areview of determinant factors of environmental proactivity, Business Strategy and Environment 15(2): 87-102. http://dx.doi.org/10.1002/bse.450

Hart, S. 1995. A natural-resource-based view of the firm, Academy of Management Review 20(4): 874-907 [online], [cited 12 September 2012]. Available from Internet: http://links.jstor.org/ sici?sici=0363-7425\%28199510\%2920\%3A4\%3C986\%3AANVOTF\%3E2.0.CO\%3B2-I

Helfat, C.; Finkelstein, S.; Mitchell, W. 2007. Dynamic capabilities: understanding strategic change in organizations. Blackwell. 
Helfat, C.; Peteraf, C. 2009. Understanding dynamic capabilities: progress along a developmental path, Strategic Organization 7(1): 91-102. http://dx.doi.org/10.1177/1476127008100133

Henriques, I.; Sadorsky, P. 1999. The relationship between environmental commitment and managerial perceptions of stakeholder importance, Academy of Management Review 42(1): 87-99. http://dx.doi.org/10.2307/256876

Hodgson, G. (Ed.) 1998. The foundations of evolutionary economics: 1890-1973. Edward Elgar.

Horbach, J. 2008. Determinants of environmental innovation - new evidence from German panel data sources, Research Policy 37(1): 163-173. http://dx.doi.org/10.1016/j.respol.2007.08.006

Horbach, J.; Rammer, C.; Rennings, K. 2012.Determinants of eco-innovations by type of environmental impact - the role of regulatory push/pull, technology push and market pull, Ecological Economics 78: 112-122. http://dx.doi.org/10.1016/j.ecolecon.2012.04.005

Kammerer, D. 2009. The effects of customer benefit and regulation on environmental product innovation. Empirical evidence from appliance manufacturers in Germany, Ecological Economics 68(8-9): 2285-2295. http://dx.doi.org/10.1016/j.ecolecon.2009.02.016

Katkalo, V.; Pitelis, C.; Teece, D. 2010. Introduction: on the nature and scope of dynamic capabilities, Industrial and Corporate Change 19(4): 1175-1186. http://dx.doi.org/10.1093/icc/dtq026

Kesidou, E.; Demirel, P. 2012. On the drivers of eco-innovations: empirical evidence from the UK, Research Policy 41(5): 862-870. http://dx.doi.org/10.1016/j.respol.2012.01.005

Langlois, R.; Robertson, P. 1995. Firms, markets, and economic change: a dynamic theory of business institutions. Routledge.

Levin, R.; Kievorick, A.; Nelson, R. R.; Winter, S. G. 1987. Appropriating the returns from industrial $R \& D$. Brookings Papers on Economic Activity.

Linton, J. D.; Klassen, R.; Jayaraman, V. 2007. Sustainable supply chains: an introduction, Journal of Operations Management 25(6): 1075-1082. http://dx.doi.org/10.1016/j.jom.2007.01.012

Markides, C. 2006. Disruptive innovation: in need of a better theory, Journal of Product Innovation Management 23(1): 19-25. http://dx.doi.org/10.1111/j.1540-5885.2005.00177.x

Mazzanti, M.; Zoboli, R. 2006. Examining the factors influencing environmental innovations. FEEM nota di lavoro 20. Fondazione En Enrico Mattei (FEEM).

Metcalfe, J. S.; Ramlogan, R. 2005. Limits to the economy of knowledge and knowledge of the economy, Futures 37: 655-674. http://dx.doi.org/10.1016/j.futures.2004.11.006

Mont, O. 2002. Clarifying the concept of product-service system, Journal of Cleaner Production 10(3): 237-245. http://dx.doi.org/10.1016/S0959-6526(01)00039-7

Nelson, R. 1991. Why do firms differ, and how does it matter?, Strategic Management Journal 12(S2): 61-74. http://dx.doi.org/10.1002/smj.4250121006

Nelson, R.; Winter, S. G. 1982. An evolutionary theory of economic change. Belknap Press.

OECD. 2012. Background paper for the Workshop on the Future of Eco-innovation, 19-20 January 2012, Copenhagen. OECD/European Commission/Nordic Innovation.

Paavola, J. 2007. Institutions and environmental governance: a reconceptualization, Ecological Economics 63(1): 93-103. http://dx.doi.org/10.1016/j.ecolecon.2006.09.026

Porter, M. E.; van der Linde, C. 1995. Toward a new conception of the environment-competitiveness relationship, Journal of Economic Perspectives 9(4): 97-118. http://dx.doi.org/10.1257/jep.9.4.97

Rave, T.; Goetzke, F.; Larch, M. 2011. The determinants of environmental innovations and patenting: Germany reconsidered. Ifo Working Paper, 97.

Del Río, P. 2009. The empirical analysis of the determinants for environmental technological change: a research agenda, Ecological Economics 68(3): 861-878.

http://dx.doi.org/10.1016/j.ecolecon.2008.07.004 
Rondinelli, D. A.; London, T. 2003. How corporations and environmental groups cooperate: assessing cross-sector alliances and collaborations, Academy of Management Executive 17(1): 61-76. http://dx.doi.org/10.5465/AME.2003.9474812

Russo, M.; Fouts, P. 1997. A resource-based perspective on corporate environmental performance and sustainability, Academy of Management Journal 40(3): 534-559. http://dx.doi.org/10.2307/257052

Schreyögg, G.; Kliesch-Eberl, M. 2007. How dynamic can organizational capabilities be? Towards a dual-process model of capability dynamization, Strategic Management Journal 28(9): 913-933. http://dx.doi.org/10.1002/smj.613

Sharma, P.; Sharma, S. 2011. Drivers of proactive environmental strategy in family firms, Business Ethics Quarterly 21(2): 309-334. http://dx.doi.org/10.5840/beq201121218

Teece, D.; Pisano, G. 1994. The dynamic capabilities of firms: an introduction, Industrial and Corporate Change 3: 537-556. http://dx.doi.org/10.1093/icc/3.3.537-a

Teece, D.; Pisano, G.; Shuen, A. 1997. Dynamic capabilities and strategic management, Strategic Management Journal 18(7): 509-533. http://dx.doi.org/10.1002/(SICI)1097-0266(199708)18:7<509::AID-SMJ882>3.0.CO;2-Z

Wagner, M. 2008. Empirical influence of environmental management on innovation: evidence from Europe, Ecological Economics 66: 392-402. http://dx.doi.org/10.1016/j.ecolecon.2007.10.001

Wagner, M.; Llerena, P. 2011. Eco-innovation through integration, regulation and cooperation: comparative insights from case studies in three manufacturing sectors, Industry and Innovation 18(8): 747-764. http://dx.doi.org/10.1080/13662716.2011.621744

Williams, A. 2007. Product service systems in the automobile industry: contribution to system innovation?, Journal of Cleaner Production 15(11-12): 1093-1103. http://dx.doi.org/10.1016/j.jclepro.2006.05.034

Worch, H.; Markard, J. 2010. Technological innovation systems and the resource based view - resources at the firm, network and system level, in DIME Workshop on Environmental Innovation, Industrial Dynamics and Entrepreneurship, 10-12 May 2010, Utrecht University.

Pablo DEL RÍO is senior (tenured) researcher and head of the Environmental Economics Group at the Institute for Public Policies and Goods at the National Research Council of Spain (CSIC). He holds a $\mathrm{PhD}$ in Environmental Economics (Universidad Autónoma de Madrid) and a MSc in Economics and Business (Universidad Autónoma de Madrid). He has more than 100 international publications in world-class journals. Research interests: drivers to eco-innovation, analysis of support schemes for the promotion of renewable energy technologies and interactions between renewable energy support schemes and $\mathrm{CO} 2$ mitigation instruments.

Javier CARRILLO-HERMOSILLA is currently a Tenured Professor at the Department of Economics and Business and a research associate of the Institute for Economic and Social Analysis at the University of Alcalá (Spain). He is also a Fellow at the Centre for European Studies Jean Monnet at IE University (Spain). Previously, he chaired the department of Economic Environment of Business and co-founded the Center for Eco-Intelligent Management at IE Business School. His research interests include researching sustainable technological change and new policy and management models that address the environmental challenge in an innovative way. His advances in the field are expounded in numerous articles and works on environmental sustainability and technological change, published in international journals and books. Furthermore, he regularly contributes to leading newspapers and media and participates as a speaker in conferences on economics, business and the environment. Prof. Carrillo-Hermosilla holds a PhD in Economics from Universidad de Alcalá (Madrid) and an MBA with Honors from IE Business School. 
Totti KÖNNÖLÄ. Doctor of Science in Technology from Helsinki University of Technology. Managing Director and Co-founder of Insight Foresight Institute (Madrid) specialised in transforming innovation ecosystems. Experienced entrepreneur, researcher and consultant in the realm of innovation and sustainability management and strategic policy intelligence. Designed and coordinated many strategic foresight, appraisal, evaluation and decision-making processes together with industry management, research directors, policy-makers and other stakeholders. Editor and author of over 100 papers and/or books in the realm of innovation, foresight and sustainability.

Mercedes BLEDA is a lecturer in Economics and Strategy at MBS. She has a first degree in economics (University of Murcia, Spain), an MPhil in dynamic economics (Dept. of Quantitative Methods, University of Murcia, Spain), and a PhD in economics from CRIC (ESRC Centre for Research on Innovation and Competition Centre) at the University of Manchester in the UK. Her research interests centre mainly in the areas of evolutionary economics and complexity theory, simulation modelling techniques, and environmental and innovation policy. She has been a researcher in several projects in these areas for the ERSC and the EPSRC, the European Commission, and other institutions at the national and local levels, both in the UK and Spain. 